\title{
Mineral grains in caddisfly pupal cases and streambed sediments: assessing resource use and its limitation across various river types*
}

\author{
Bernhard Statzner** \\ CNRS-Écologie des Hydrosystèmes Fluviaux, University of Lyon 1, 69622 Villeurbanne Cedex, France
}

Received 17 November 2010; Accepted 4 February 2011

\begin{abstract}
Typically, lotic caddisflies attach their mineral pupal cases to cobbles in riffles, where rapid flows facilitate respiration but also decrease case-building material availability through erosion. Effects of local grain availability on grain quantities in and architecture of (per capita grain size use) pupal cases should be more important in Resident Construction Workers (RCWs, building immediately before pupation with minerals collected near the pupation location) than in Itinerant Construction Workers (ICWs, building months before pupation with minerals collected distantly from the pupation location). I tested these hypotheses analyzing mineral grain sizes in pupal cases and streambed sediments of cobble habitats in riffles of five running water types (headwater to large river in different regions) at baseflow or exceptional droughts. When pupae were abundant, the data supported both hypotheses at the local scale of samples, as grain size use by RCWs (as a group) but not by ICWs increased across all sites with local grain availability and abundant taxa among the former responded with four types of case-architecture modifications to grain size shortage. The data also supported the idea that at larger scales such as river or habitat types, mineral grains may be a limited resource for caddisflies building pupal cases with them. These findings suggest that water currents in streams or near shores of lakes and oceans that erode finer mineral grains can create conflicts in resource requirements for invertebrates that build with locally occurring finer mineral grains and simultaneously need high oxygen renewal rates and coarse grains for attachment.
\end{abstract}

Key words: Benthos / case architecture / interspecific competition / scale effects / Trichoptera

\section{Introduction}

Effects of resource limitations on survival, growth, and performance of plants and animals are so evident that they were discovered in the pioneer age of ecology (e.g., Liebig, 1840; Semper, 1880). Today, resource limitations figure prominently in ecology textbooks when these address the potential role of intra- or interspecific competition for resources in determining niche dimensions, community composition, and diversity (e.g., Begon et al., 1986). We now understand how resources that are seemingly overabundant can be limited because of subtle constraints interfering with their use. For example, dissolved inorganic carbon $(\mathrm{C})$ in seawater is so abundant relative to other plant nutrients that the potential role of inorganic $\mathrm{C}$ acquisition in marine phytoplankton ecology and

\footnotetext{
*Dedicated to the memory of Bert Higler, who was an active and diversified Trichopterologist.

**Corresponding author: bernhard.statzner@univ-lyon1.fr
}

evolution received little interest, until the discovery of related enzyme activities suggested potential inorganic $\mathrm{C}$ limitations of planktonic algae in marine systems (see Buitenhuis et al., 2003; Rost et al., 2003). Similarly to this example, the large quantities of sand and fine gravel in streambed sediments are a seemingly overabundant resource, and this article deals with the subtleties in the use of this resource by caddisflies larvae that build a pupal case from it.

Building tubes or cases from mineral or organic particles is a technique that is used by taxonomically very different aquatic animals and the degree of selectivity in the use of particles for building in relation to particle availability has been a major thread in studies of their biology and ecology (Dudgeon, 1990). Among the insects, the larvae of caddisflies build cases from mineral or organic particles that are cemented with silk, which is considered as essential for the evolutionary success of this order (Mackay and Wiggins, 1979). Therefore, hundreds of scientific publications deal with the case architecture 
of caddisflies (i.e., the use of various building materials that define the potential case structure and function), considering its style, its control, or its functional significance (e.g., see Wiggins, 2004).

Concerning the construction style of caddisfly cases, it is naturally often so conservative that it serves as one character in identifications (e.g., Gónzalez et al., 1989; Waringer and Graf, 1997; De Moor, 2005). However, if the commonly used material is unavailable in experiments, larvae typically use other case-building material being as close as possible to the preferred one (Gorter, 1931). For example, species building cases preferably with a certain grain size range of mineral particles switch to grain sizes near the range limits of the unavailable, normally preferred one (Hanna, 1961; Tolkamp, 1980).

Concerning the control of the case architecture by the larvae, caddisflies use mouthparts and legs as tools to measure the particle size required at a given moment of case construction and to select the appropriate mineral size, or to shape organic material accordingly (Gorter, 1931; Hansell, 1974; Stuart and Currie, 2001). In addition, bristles and other sensors provide information about the required case length or diameter (Hansell, 1973). As the size of the tools and the distance between the sensors increase during larval growth, the size of the building material and the case itself typically become larger with increasing larval size (e.g., Gorter, 1931; Hanna, 1961; Tolkamp, 1980), and many species change the overall case architecture in a certain development stage (Dudgeon, 1990).

Concerning the functional significance of the cases, there is variable evidence for one or another function, which simply reflects the diverse role that cases may play in the life of caddisflies. The cases have been supposed to provide, e.g., ballast, buoyancy, streamlining, camouflage, mechanical protection against predators or crushing by flood-induced movements of coarser bed sediments, and better respiratory efficiency, but almost any of these functions has been questioned because of contradictory evidence (e.g., Williams et al., 1987; Otto and Johansson, 1995; Otto, 2000; Statzner et al., 2009; Okano et al., 2010). However, despite this debate about the details, the overall functional importance of the cases for the larvae and pupae is undisputed (Williams and Feltmate, 1992; Solem and Gullefors, 1996), particularly because case construction requires energy that is not available for larval growth (Dudgeon, 1990). These energetic costs for case construction are affected by case architecture, as the volume of silk required cementing organic or mineral particles together increases with decreasing particle size (Smart, 1976; Becker, 2001).

Given that caddisflies are often conservative builders, the availability of the preferred mineral case material has been repeatedly discussed as a limiting factor at larger scales such as river or habitat types (e.g., Hanna, 1961; Tolkamp, 1980; De Moor, 2005; Takao et al., 2008). However, there is little evidence that suitable mineral casebuilding material is limiting to lotic caddisflies at smaller scales (Dudgeon, 1990), presumably because larvae that carry their cases with them can migrate $\sim 1-4$ m per day (Elliott, 1971; Jackson et al., 1999), move to locations providing the preferred grain size when building cases (Mackay, 1977; Podgornyi and Nepomnyashchikh, 1999), and use far fewer grains than those being available in nature (Tolkamp, 1980). Typically, these case-carrying larvae add material to the case front and cut the case back off after each larval molt, and pupate in the larval case after they have fixed it to coarser material (e.g., a cobble) on the stream bottom (Waringer and Graf, 1997; Malicky, 2000; Wiggins, 2001). Thus, these "Itinerant Construction Workers" (ICWs) acquire the building material for the pupal case distant from the pupation location during their larval life (although a few among the limnephilids and brachycentrids build new cases prior to pupation; Zwick, 1998; Malicky, 2000; Wiggins, 2001). Consequently, ICWs should typically not be limited by the availability of building material near the locations where they fix their pupal cases. In contrast, glossosomatid and particularly hydropsychid and rhyacophilid larvae are "Resident Construction Workers" (RCWs), as they construct immediately before pupation an entirely new pupal case with sand and fine gravel from the neighborhood of the building place. Typically, they fix the pupal cases at the building place to cobbles in fast flowing stream riffles (Haller, 1948; Sattler, 1958; Lepneva, 1970; Bohle and Fischer, 1983; Waringer and Graf, 1997). The fast flow in cobble habitats of stream riffles facilitates oxygen uptake and cobbles provide solid surfaces for case attachment, whereas the erosive flow forces prevailing near the bottom reduce the amount of sand and fine gravel (Hynes, 1970; Newbury and Gaboury, 1993). Thus, these riffle-dwelling RCWs potentially have conflicting resource requirements, suggesting that finer mineral grains needed for the pupal case construction could be a limited resource for them.

Studying this idea at one riffle site, Statzner et al. (2005) found that the overall mass use in pupal cases of Rhyacophila and particularly Hydropsyche significantly increased with local mass availability of building material, indicating that mineral grains can be a limited resource for these RCW taxa. In addition, the most abundant species (H. siltalai Döhler) significantly changed the case architecture if the preferred grain fraction $(2.5-3.15 \mathrm{~mm})$ was a locally limited resource. Under resource limitation of the preferred fraction, $H$. siltalai used more grains of the fractions $1.6-2 \mathrm{~mm}$ and $0.315-0.5 \mathrm{~mm}$ instead, which both were unlimited resources. Here, I expand this previous field study to several running water types from different French regions (ranging in size from headwater to large river) and more species to test two hypotheses. Firstly, at the local scale of samples, grain quantities (mass of grain fractions) in pupal cases should increase with grain availability (mass of grain fractions) in RCWs but not (or only marginally) in ICWs. Secondly, local case architecture in terms of per capita mass use of grain fractions by RCW taxa should be affected by local per capita mass availability of grain fractions. Beyond tests of these hypotheses, the data provided unplanned insights into consequences of different grain size availability at the larger scale (across 
rivers) for the abundance of larger $\mathrm{RCW}$ taxa and into the co-existence of closely related RCW species (of the genus Hydropsyche) using similar grain sizes.

\section{Material and methods}

\section{Study sites}

Expanding previous work on caddisfly pupal cases from the Furan River (Statzner et al., 2005), I re-use published data on RCWs from that study that contributed to tests of the hypotheses of the present study (avoiding repetition about taxon specific grain resource limitations). In addition, I use unpublished data on ICWs from that previous study and on RCWs and ICWs from four other rivers of varying size that are running through regions without or with different well-known wines (Johnson and Duijker, 1993), which is a clear sign for differences in soil and climate among them.

The Furan is situated in the Bugey Massif, which is in the southern part of the Jura Massif. It is a tributary of the French Upper Rhône River and joins the latter $5 \mathrm{~km}$ south of the city of Belley. The studied section is situated at $05^{\circ} 39^{\prime} 32^{\prime \prime} \mathrm{E} / 45^{\circ} 44^{\prime} 26^{\prime \prime} \mathrm{N}$ (near the village Thoys; for maps and aerial photographs of this and other regions covered here see http://www.geoportail.fr; for more details on the study site see Statzner and Bretschko, 1998). Two other of the studied rivers are also situated in the Jura Massif. The Cusancin River, in the northern part of this massif, flows via Doubs into the Saône, which is the largest tributary of the Rhône. The study site is situated at $06^{\circ} 25^{\prime} 31^{\prime \prime} \mathrm{E} /$ $47^{\circ} 19^{\prime} 26^{\prime \prime} \mathrm{N}$ (near the village of Cusance) and described in more detail by Verneaux (1973). The Cuisance is situated in the central part of the Jura and flows also via Doubs into the Saône. The study site (at $05^{\circ} 48^{\prime} 24^{\prime \prime} \mathrm{E} / 46^{\circ} 52^{\prime} 50^{\prime \prime} \mathrm{N}$ ) is below the village of Les Planches-près-Arbois (for more details on the site see Verneaux (1973)). The Bez is draining a large part of the Diois Massif, which is part of the foothills of the Southern Alps (for more details on the Bez see Abdoli et al., 2005). It flows into the Drôme, which is an eastern tributary of the Lower Rhône. The study site is situated downstream of Châtillon-en-Diois at $05^{\circ} 28^{\prime} 19^{\prime \prime} \mathrm{E} /$ $44^{\circ} 41^{\prime} 10^{\prime \prime} \mathrm{N}$. Two of these four study sites were in headwaters (Cusancin and Cuisance) and the other two were in intermediately sized, yet wadable rivers; all four running waters belong to the catchment of the Rhône, which flows into the Mediterranean Sea. In contrast, my fifth study site is on a large river from a different catchment, the Loire, which drains the Central Massif and flows into the Atlantic. The study site is situated on the left side of the river near the village Chambilly at $04^{\circ} 00^{\prime} 53^{\prime \prime} \mathrm{E} / 46^{\circ} 16^{\prime} 42^{\prime \prime} \mathrm{N}$ (for more details on this site see Ivol et al. (1997)).

All these five sites were studied in summer when pupation of most caddisflies typically peaks, i.e., the sites were visited at baseflow conditions. However, discharge was extremely low during the first visit of the Cuisance in 2003, when the summer was extremely hot and dry. Consequently, the $\sim 2-\mathrm{km}$-long tributary fed by the
"Petite" source of the Cuisance was almost dry and most of the discharge at the study site came from the tributary fed by its "Grande" source. Therefore, I repeated the 2003survey at the Cuisance site in the summer of 2005, when the baseflow discharge was near "normal" (i.e., discharge at the nearest gauging site in Mesnay was $\sim 3$-times higher than in 2003 and the tributary fed by the "Petite" source was "normally" flowing). Because the river network in the catchment was so different in the two years, I henceforth refer to the two data sets as site "Cuisance03" and site "Cuisance05". At all occasions, stony riffle habitats with a relatively high bottom shear stress were assessed at these sites. Given that bottom shear stress expressed in N.m ${ }^{-2}$ is approximately critical for a grain size expressed in $\mathrm{mm}$ (e.g., Newbury and Gaboury, 1993), the shear stress ranges assessed in this study (see Table 1) could erode sand at the lower and typically finer gravel at the upper end.

\section{Data collection and analyses}

From a preliminary study described in Statzner et al. (2005), I knew that the intraspecific variability of the details in pupal case architectures of RCWs at similar habitat conditions can be relatively high and that it requires many specimens per species and many samples to discover effects of grain availability on grain use. Therefore, I stratified the riffles in the study sites and randomly sampled cobble $(\sim 6-20 \mathrm{~cm})$ substrates with a relatively high shear stress (see Table 1), as these conditions are typically used by many RCWs and ICWs for pupation. Sampling only cobble substrates does not imply complete absence of finer sediments, as smaller patches of sand and finer gravel occurred locally among the cobbles. In the Furan, I took 50 quantitative samples on one day each at two occasions during the period of highest pupal density (June and July 1998), followed by 30 samples each over subsequent months. From these, only the August samples contained sufficient identifiable pupal cases to be included here. Statzner et al. (2005) reported temporal stability of overall grain availability and use (for RCWs) across these three dates (confirmed here for overall grain use by ICWs through a Kruskal-Wallis tests on differences among dates $(P=0.450))$, so I pooled these data to obtain a sample size of 129 quantitative samples (one sample was lost because of a mishap). At the other sites, 50 quantitative samples each were obtained at one occasion on 1-2 days during the peak pupal season (Table 1; note that one sample from the Bez was also lost).

Quantitative sampling of finer sediments in the sediment layer used by caddisfly larvae for pupation requires observations of pupal occurrence during sampling and thus more standardization than conventional benthos sampling. Therefore, I took all the benthos samples myself, marking the area of each quantitative benthos sample with a metal frame $(0.3 \mathrm{~m} \times 0.2 \mathrm{~m})$ and positioning a net with a fine mesh size $(0.1 \mathrm{~mm})$ immediately downstream of the frame. I agitated the finer sediments among the cobbles in the frame so that they were washed by the current into 
Table 1. Sampling period and sample size, shear stress range (assessed with FST-hemispheres; Statzner et al., 1991) and pupal abundance (mean \pm 1 S.E. individuals $0.06 \mathrm{~m}^{-2}$ ) at the study sites. Taxa names in bold italics indicate Resident Construction Workers $(\boldsymbol{R} \boldsymbol{C} \boldsymbol{W} \mathrm{s})$ and taxa names in simple italics indicate Itinerant Construction Workers (ICWs). If taxa of a genus could not be safely identified to species using larval exuvia and/or overall case architecture, species identifications of mature pupae are indicated as footnotes.

\begin{tabular}{|c|c|c|c|c|c|c|}
\hline$\overline{\text { Item }}$ & Furan & Cusancin & Cuisance03 & Cuisance05 & Loire & $\overline{\mathrm{Bez}}$ \\
\hline Period & Summer 1998 & June 2003 & June 2003 & June 2005 & June 2005 & July 2007 \\
\hline Size $(N)$ & 129 & 50 & 50 & 50 & 50 & 49 \\
\hline Shear stress $\left(\right.$ N.m $\left.{ }^{-2}\right)$ & $0.8-2.3$ & $0.3-1.1$ & $0.2-1.6$ & $0.8-2.3$ & $0.7-3.2$ & $0.8-9.0$ \\
\hline Agapetus fuscipes Curtis & 0 & $1.2 \pm 0.3$ & $0.2 \pm 0.1$ & $0.02 \pm 0.02$ & 0 & 0 \\
\hline $\begin{array}{l}\text { Athripsodes leucophaeus } \\
\text { (Rambur) }\end{array}$ & 0 & 0 & 0 & 0 & $0.5 \pm 0.2$ & 0 \\
\hline $\begin{array}{l}\text { Cheumatopsyche lepida } \\
\text { (Pictet) }\end{array}$ & 0 & 0 & 0 & 0 & $0.2 \pm 0.1$ & 0 \\
\hline $\begin{array}{l}\text { Glossosoma bifidum } \\
\text { McLachlan }\end{array}$ & 0 & $10.1 \pm 1.2$ & $3.9 \pm 0.9$ & $0.1 \pm 0.04$ & 0 & 0 \\
\hline $\begin{array}{l}\text { Hydropsyche contubernalis } \\
\text { McLachlan }\end{array}$ & 0 & 0 & 0 & 0 & $19.0 \pm 1.4$ & 0 \\
\hline H. dinarica Marinkovic & 0 & $0.9 \pm 0.2$ & $0.02 \pm 0.02$ & $0.2 \pm 0.1$ & 0 & $0.1 \pm 0.1$ \\
\hline H. exocellata Dufour & 0 & 0 & 0 & 0 & $11.7 \pm 1.2$ & 0 \\
\hline H. incognita Pitsch & 0 & 0 & 0 & 0 & $4.7 \pm 0.7$ & $0.3 \pm 0.1$ \\
\hline H. instabilis (Curtis) & 0 & 0 & $2.8 \pm 0.5$ & $0.6 \pm 0.1$ & 0 & $6.0 \pm 1.0$ \\
\hline H. siltalai Döhler & $15.1 \pm 1.1$ & 0 & $0.02 \pm 0.02$ & 0 & 0 & 0 \\
\hline $\begin{array}{l}\text { Odontocerum albicorne } \\
\text { (Scopoli) }\end{array}$ & $5.4 \pm 0.7$ & $0.1 \pm 0.1$ & $0.3 \pm 0.1$ & $0.8 \pm 0.2$ & 0 & $1.0 \pm 0.4$ \\
\hline Potamophylax & $0.6 \pm 0.2^{\mathrm{a}}$ & $0.1 \pm 0.1^{\mathrm{b}}$ & 0 & 0 & 0 & 0 \\
\hline Rhyacophila & $6.0 \pm 0.4^{c}$ & $0.6 \pm 0.2$ & $15.1 \pm 0.9^{\mathrm{d}}$ & $3.8 \pm 0.4^{\mathrm{d}}$ & $0.1 \pm 0.04^{\mathrm{e}}$ & $1.9 \pm 0.4^{\mathrm{e}}$ \\
\hline R. fasciata Hagen & 0 & 0 & $0.4 \pm 0.1$ & $0.1 \pm 0.1$ & 0 & 0 \\
\hline $\begin{array}{l}\text { Sericostoma personatum } \\
\text { (Kirby \& Spence) }\end{array}$ & 0 & 0 & 0 & 0 & 0 & $4.0 \pm 1.2$ \\
\hline Silo nigricornis (Pictet) & $2.0 \pm 0.2$ & $0.1 \pm 0.1$ & $0.02 \pm 0.02$ & $0.1 \pm 0.1$ & 0 & 0 \\
\hline
\end{tabular}

${ }^{\mathrm{a}}$ P. cingulatus (Stephens) \& P. luctuosus (Piller \& Mitterpacher).

${ }^{\mathrm{b}} P$. cingulatus.

${ }^{\mathrm{c}} R$. fasciata \& $R$. dorsalis Curtis.

${ }^{\mathrm{d}} R$. vulgaris Pictet.

${ }^{\mathrm{e}} R$. dorsalis.

the net and removed the surface layer and approximately the first subsurface layer of cobbles from the frame (note that deeper substrate layers had cobble interstices filled with finer sediments and lacked caddisfly pupal cases). All removed cobbles were put into a basin with water. At the end of sampling, I again agitated the finer sediments in the metal frame to wash them into the net. Thus, the procedure tried to sample all sand and fine gravel from the surface and first subsurface layer of the cobble bottom. Although these finer sediments contributed to the estimates of building material availability (see below), it is obvious that not all these sediments were really accessible for caddisflies, which makes tests of potential grain resource limitations for RCWs more conservative.

Using sharp knives, the silk of the pupal cases fixing them to the cobble surfaces was cut so that the entire cases dropped into the basin with water. After washing finer sediments from the cobbles, the cases and the finer sediments from the basin were filtered with the net containing the finer sediments collected from the sampled area and the retained material was conserved in ethanol $(70 \%)$.

In the laboratory, the entire pupal cases and fragments of empty cases were sorted and case-bearing larvae of caddisflies were removed from the samples. The difficulty to identify a caddisfly pupal case safely to species varies with the age of its occupant. Mature European caddisfly pupae are relatively easy to identify using the structure of the genitalia and the monograph of Malicky (1983), whereas prepupae show all characteristics of the last larval instar (used keys: Waringer and Graf, 1997; Higler, 2005). In contrast, immature pupae are very difficult to identify, although in hydropsychids, rhyacophilids, and glossosomatids, pieces of the larval exuvia from the pupal cocoon may facilitate identifications. In my material, identifications of immature pupae of hydropsychids and glossosomatids were relatively easy due to descriptions of numerous sclerotized parts on head and abdomen provided by Waringer and Graf (1997), Neu and Tobias (2004), Statzner and Mondy (2009), and Statzner et al. (2010), whereas those of rhyacophilids were often too difficult to put a name on each specimen sampled at a site. In comparison to pupal cases of RCWs, ICW cases contain rarely parts of the larval exuvia so that the coincidence larval exuvia-mature genitalia is even rarer. As most of the species had a relatively typical pupal case architecture, this helped to assign immature pupae to species. 
Silk of the identified cases and the unidentified case fragments was dissolved in a $\mathrm{NaOH}$-solution and the case material was dried for $48 \mathrm{~h}$ at $105{ }^{\circ} \mathrm{C}$. Likewise, the remaining sediments of the sample were dried. The dried case material (pooling all cases per taxon and sample) and the dried remaining sediments were separated with a set of sieves having the mesh size of $10,5,4,3.15,2.5,2,1.6$, $1.25,1,0.8,0.5,0.315,0.25$, and $0.125 \mathrm{~mm}$, and each fraction was weighted. Larger RCW species sometimes had grains of the fraction 5-10 $\mathrm{mm}$ in the upper case wall, and sometimes they had built their cases among even larger gravel pieces (using these as foundation for the case). Assuming that the larvae were unable to collect these even larger gravel pieces, I ignored material $>10 \mathrm{~mm}$ in the analyses.

I calculated building material availability as described by Statzner et al. (2005), ignoring the size $<0.125 \mathrm{~mm}$ (because the mesh size of the field net was $0.1 \mathrm{~mm}$ ) and using all the remaining sediments of a sample, plus the fragments of the empty pupal cases, plus half of the material used in the pupal cases of the RCWs. The rationale to include half of the material used in RCW cases in this calculation related to the observation that the pupal cases in a sample could contain all development stages (prepupa to mature pupa). Thus, some of the cases were build shortly before sampling, whereas others were built weeks before sampling, i.e., the latter should have had material available for building that was unavailable for the former. Therefore, adding half of the material found in the pupal cases of the RCWs to the available sediment quantities was an arbitrary correction for the temporal differences in building activities.

Overall, I varied the sample size in analyses of sediment availability and use to address previous assessments of intraspecific case variability within samples (e.g., the error of mean value estimates per sample dropped below $5 \%$ for $\geq 10$ pupal cases; Statzner et al., 2005). Therefore, I reduced the data to samples with abundant pupae $(\geq 10$ cases per RCW, ICW, or abundant RCW taxon) when analyzing patterns in relation to my first and second hypothesis. Likewise, when illustrating overall pupal case architecture of taxa at a site, I omitted taxa that were too rare (occurred in fewer than three samples) and used mean values of grain use from all samples containing a given taxon. Because of these varying sample sizes, statistical analyses made sometimes no sense and were deliberately not communicated (e.g., very similar patterns were statistically significant because of great sample sizes, whereas very different patterns were statistically similar because of small sample sizes). When appropriate, I used Systat $-10^{\circledR}$ for correlation and regression analyses.

\section{The caddisflies: site abundances and details on their pupal case biology}

Overall, pupae of 18 species occurred in the samples, 12 of them RCWs and 6 of them ICWs, and typically the latter were less abundant than the former (Table 1). In the
Cuisance, pupal abundance of all RCWs except $H$. dinarica was higher during the drought in 2003 than at "normal" baseflow in 2005 (Table 1).

With seven species (six Hydropsyche, one Cheumatopsyche), the hydropsychid was the speciesrichest family of the study and the Loire site housed most (four) species of this family (Table 1). Three monographs provided detailed background information on the biology of larval and pupal European Hydropsyche (Haller, 1948; Sattler, 1958; Schuhmacher, 1970). Prior to pupation, the larvae of Hydropsyche leave their larval retreat and migrate around before they start to build the pupal case using the surface of larger particles as foundation. Haller (1948) and Sattler (1958) observed that larvae always have abdominal contact with the building place when searching mineral grains for the case. However, Mogel et al. (1985) observed that larvae make short excursions into the neighborhood of the location where they construct the pupal case, to collect sand and fine gravel that is pushed with the head or transported with the mandibles. If two Hydropsyche larvae simultaneously construct pupal cases in adjacent locations, they try to steal material from the other's larva building place, which provokes attack by the owner and escape by the burglar (Mogel et al., 1985). The larvae need about one day to construct the pupal case (Sattler, 1958; Mogel et al., 1985). The final product is a domed case on a larger bedplate, with the dome made of mineral grains that are cemented together with silk. Inside the case is a silken cocoon, which contains the larva, and the cocoon has fine openings in the front and in the back so that water can enter and leave (Sattler, 1958). The subsequent prepupal phase lasts $\sim 2-5$ days. The prepupa is immobile and during this phase mortality rates are much higher than in the pupal phase, because abdominal undulations of the pupa actively transport oxygen-rich water through the cocoon (Sattler, 1958; Schuhmacher, 1970). Depending on the temperature, the pupa emerges after 2-4 weeks (Schuhmacher, 1970).

Three other species of RCWs considered in this study were from the subgenus Rhyacophila sensu stricto (Table 1). The first case constructed by the larvae of this group is the pupal case, which resembles that of Hydropsyche (although the inner cocoon differs) (Waringer and Graf, 1997). Confirmed species identifications of larvae are currently often impossible in this species group (Waringer and Graf, 1997), making it difficult to identify prepupae and immature pupae to species. The life cycle of Rhyacophila species is often untypical, as prepupae and pupae can be found spread over many months of the year and the data suggest that their builders use the pupal case for $\sim 2-5$ months (Céréghino et al., 1997; Sangpradub et al., 1999).

Finally, I assigned two glossosomatid species (A. fuscipes, G. bifidum) to the RCWs because glossosomatids collect their pupal case material from an area that is smaller (Bohle and Fischer, 1983) than the area quantitatively sampled in this study. The pupal case architecture in various genera of this family is very similar to that of Rhyacophila, although glossosomatids are perhaps less constrained by local grain availability 
than hydropsychids and rhyacophilids. For example, Synagapetus larvae build parts of the future pupal case in one place (typically where a larger stone is in contact with finer grains) and migrate with this building to a place that is exposed to the current (typically a stone surface). There, they fix the incomplete case and finish the building over the next 1-2 days (Bohle and Fischer, 1983).

Within the ICWs, all six species studied here (see Table 1) fix their larval case with silk to the surface of larger bottom particles and pupate in it. However, their pupal cases may have some mineral pieces that are lacking in the larval case (see Lepneva, 1971), which the larvae presumably have to find close to the location where they pupate. At the Loire site I found many larvae of a leptocerid (A. leucophaeus) that have so far not been described (Waringer and Graf, 1997). I assigned them to this species through the typical, unique case type (a tube made from very fine grains) at the Loire site and the genitalia of mature pupae. It was also easy to identify larvae, pupae, and cases of the odontocerid $O$. albicorne. This species has a cylindrical sand case, to which the larva adds a few gravel pieces prior to pupation (see Lepneva, 1971). Likewise, it was easy to identify $S$. nigricornis, which was the only goerid in this study. Its pupal case has a central tube of sandy material, laterally small pieces of gravel, and a gravel piece closing the anterior tube opening. In comparison, it was more difficult to identify larvae and pupa of the sericostomatid $S$. personatum (too similar to S. flavicorne; Waringer and Graf, 1997), but the 45 pupae with mature genitalia found in the Bez belonged doubtless all to this species. Its pupal case is a curved tube made from finer grains. The last two ICW species included here were from the genus Potamophylax, but it was not possible to identify their immature pupae to species. Recent observations suggest that Potamophylax larvae occasionally construct an entire new mineral case prior to pupation (Malicky, 2000), but I never found case architectures in this study (in comparison to illustrations in Malicky (2000)) that supported these observations.

\section{Results}

\section{Overall grain availability and overall pupal case architecture}

Across the grain size range used in the pupal cases by the 18 species studied here, the fraction 5-10 $\mathrm{mm}$ contributed more than any other fraction to the available grain mass at all sites (Fig. 1). This predominance was primarily caused by the much greater size range of the largest fraction $(5 \mathrm{~mm})$ if compared to the other fractions (all together $4.875 \mathrm{~mm}$ ). If compared to all other fractions together (i.e., $<5 \mathrm{~mm}$ ), the largest fraction remained predominant in Cusancin and Bez, was about similar in Furan and Cuisance03, and was inferior in Cuisance05 and Loire. Grain mass in the fractions $<5 \mathrm{~mm}$ (the predominantly used grain size, see below) was $<1 \mathrm{~kg} . \mathrm{m}^{-2}$ in the Cusancin, $\sim 2 \mathrm{~kg} \cdot \mathrm{m}^{-2}$ in the Furan, and between
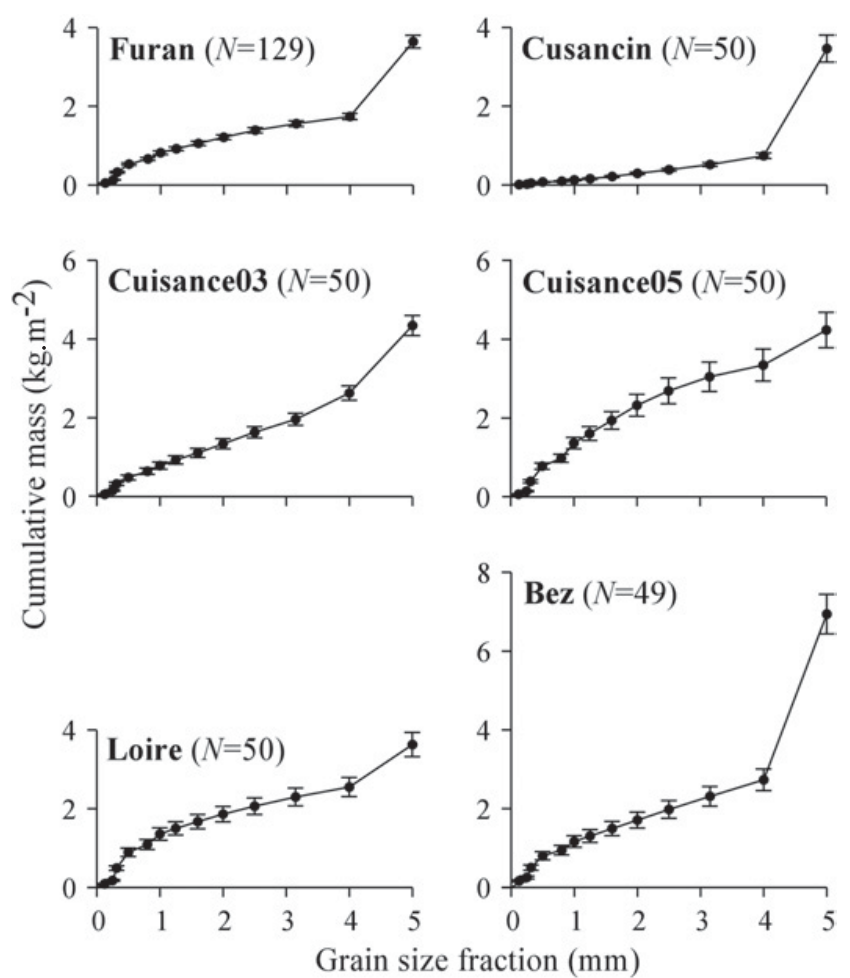

Fig. 1. Overall grain availability, showing mean \pm 1 S.E. of the cumulative grain dry mass for all samples per site (note that grains $<0.125 \mathrm{~mm}$ were not quantitatively sampled and ignored here and in all other figures that address availability). Here and in subsequent figures, grain size indicates the lower size limit of a given sieve fraction.

2-3 kg.m ${ }^{-2}$ at the other sites except Cuisance05 $\left(>3 \mathrm{~kg} . \mathrm{m}^{-2}\right)$. Among the grains $<5 \mathrm{~mm}$, the cumulative mass increase was steeper across smaller than larger grains at all sites but Cusancin (Fig. 1), i.e., grain availability of smaller grains was typically above that of larger grains.

On average, the grain fraction 5-10 $\mathrm{mm}$ was either only exceptionally used or, when regularly used by species of Hydropsyche and Rhyacophila, was typically less used than smaller grains (Fig. 2). Overall, $H$. dinarica had the heaviest and $A$. leucophaeus the lightest pupal cases. Despite of the considerably differences in the case architecture between these two and other taxa (Fig. 2), all sites had more than one species using the same (some or all) grain fractions in their pupal cases, although the relative use per species of these fractions in comparison to the entire grain use often differed among the species.

In the Cusancin, where smaller grains were relatively rare (see Fig. 1), more larger grains were used by $H$. dinarica if compared to its grain use in the Bez and by Rhyacophila if compared to its grain use at all other sites it occurred. In contrast, also in the Cusancin, fewer larger grains were used by G. bifidum if compared to its grain use in the Cuisance 03 and by $O$. albicorne and $S$. nigricornis if compared to their grain use at all other sites they occurred. Finally, A. fuscipes had a similar grain use in Cusancin and Cuisance03. Thus, a given grain availability at a site in comparison to other sites produced variable grain use 

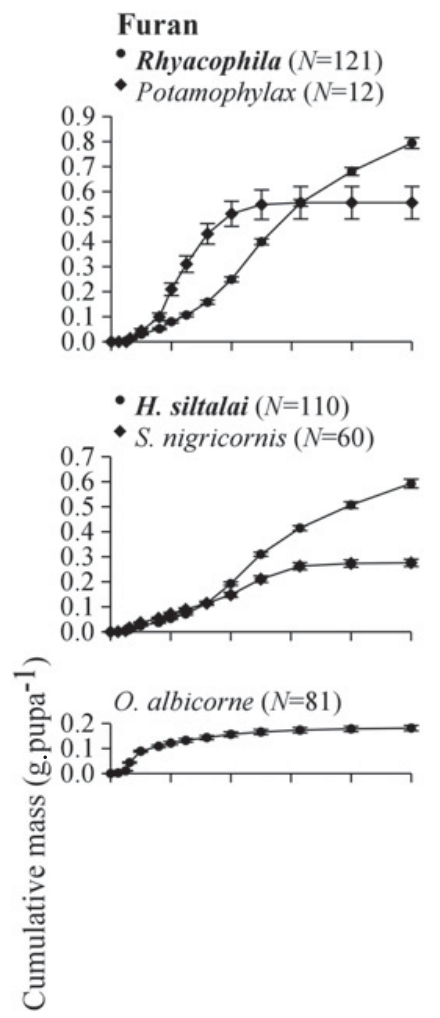

- Rhyacophila $(N=3)$

- H. contubernalis $(N=50)$
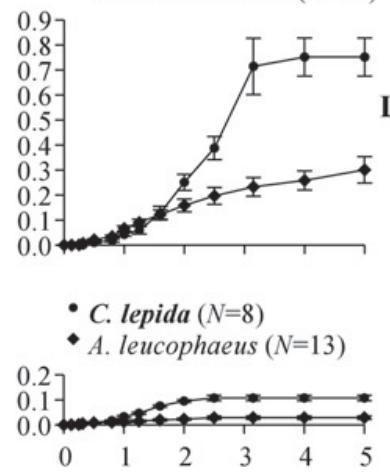

- H. incognita $(N=42)$
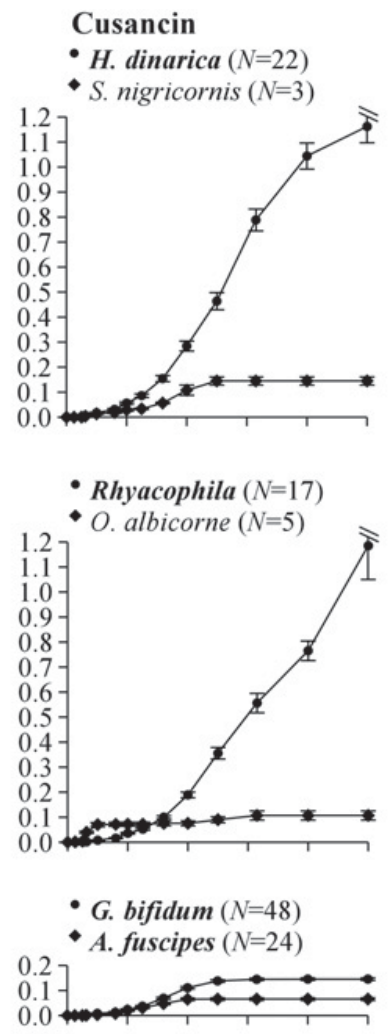

Cuisance03

- H. instabilis $(N=41)$

- Rhyacophila $(N=50)$
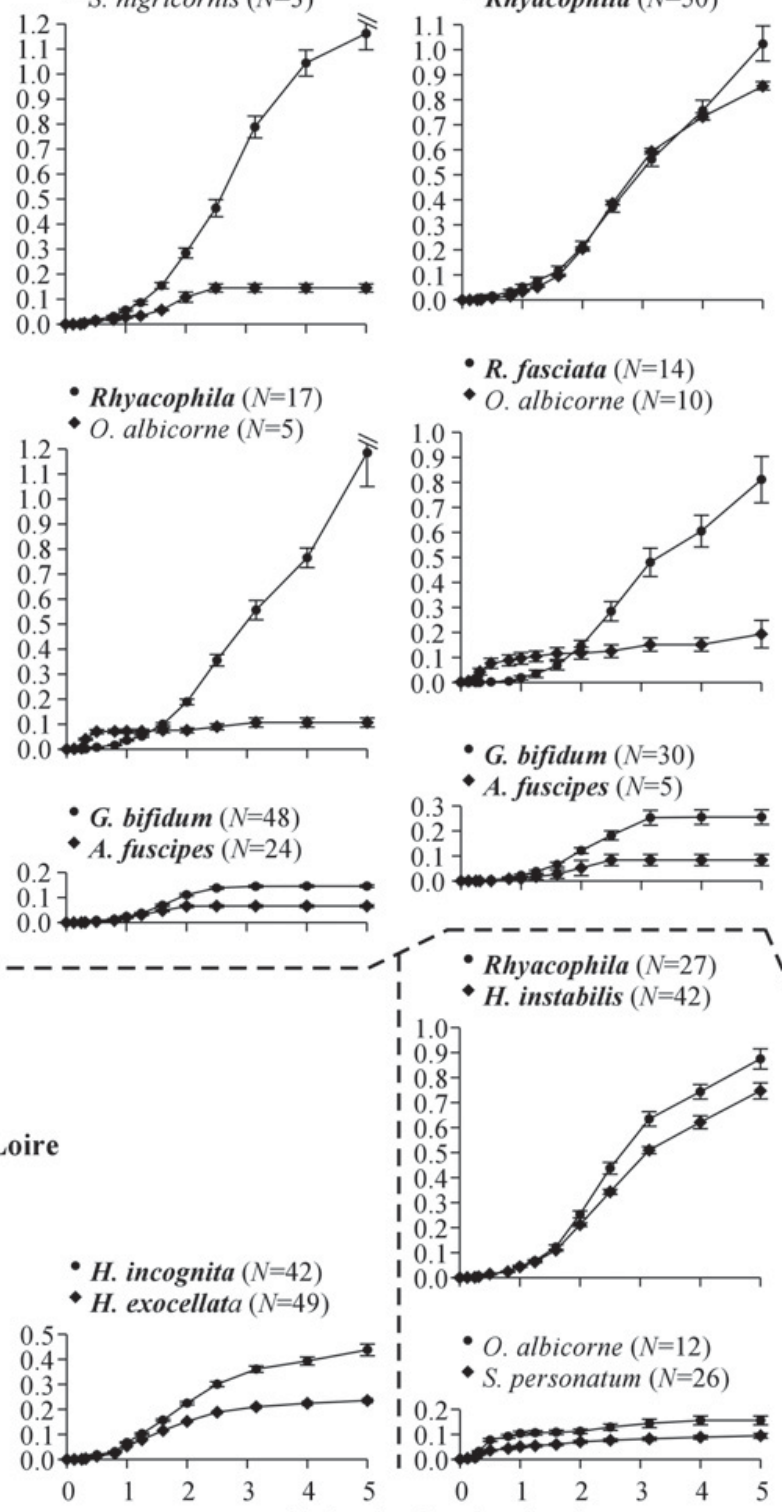

Loire
- $O$. albicorne $(N=12)$

- S. personatum $(N=26)$

0.27
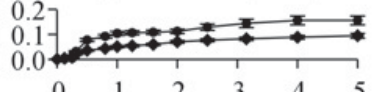

Grain size fraction $(\mathrm{mm})$

Cuisance05

- R. fasciata $(N=3)$

- O. albicorne $(N=15)$

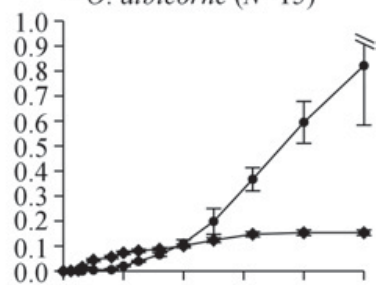

H. instabilis $(N=21)$

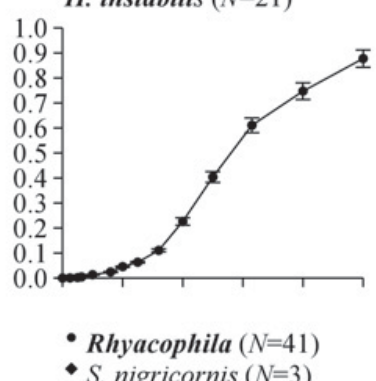

- S. nigricornis $(N=3)$

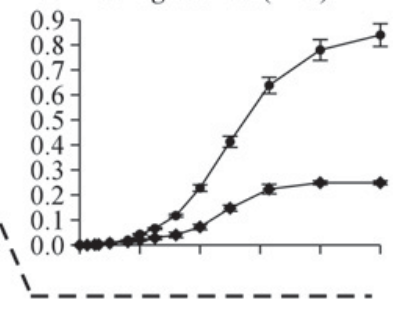

Bez

- H. dinarica $(N=5)$

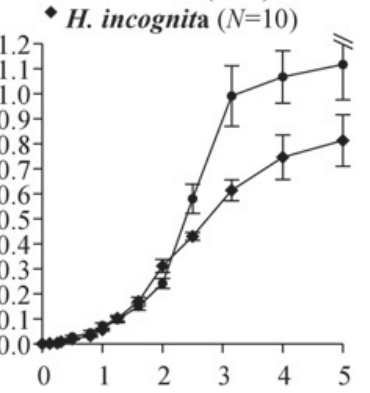

Fig. 2. Overall pupal case architecture of individual taxa of Resident Construction Workers ( $R \boldsymbol{C W} \mathbf{s})$ and Itinerant Construction Workers $(I C W \mathrm{~s})$, showing mean \pm 1 S.E. of the cumulative grain dry mass for all samples at the sites a taxon was found (if it occurred at least in three samples per site).

responses among $\mathrm{RCW}$ species and seemingly did not constrain grain use by ICWs.

Among the hydropsychids, $H$. dinarica was the largest (head width $\sim 2.25 \mathrm{~mm}$ ) and $C$. lepida the smallest $(\sim 0.85 \mathrm{~mm})$ species (Statzner et al., 2010), and this difference was clearly mirrored in the grain size use in their pupal cases (Fig. 2). Between these two extremes, the overall size of used grains decreased from $H$. instabilis to $H$. incognita in the Bez, $H$. siltalai, $H$. incognita in the Loire, and finally to $H$. exocellata and $H$. contubernalis (both only found in the Loire). Thus, in the Loire, the three Hydropsyche species had a relatively similar overall grain size use. Among the ICWs, the Potamophylax species were by far the largest. Correspondingly, their overall case mass was clearly above that of the other four ICWs. However, compared to Hydropsyche and Rhyacophila, they used fewer large grains despite a similar body size (almost all grains used by Potamophylax were $<2 \mathrm{~mm}$ ) (Fig. 2).

\section{Grain availability/use and case architecture at high pupal densities ( $\geq 10$ pupae per sample)}

RCWs vs. ICWs across all taxa and sites

Reducing the samples to those having $\geq 10$ pupae each of RCWs and/or $\geq 10$ pupae each of ICWs, the results are 


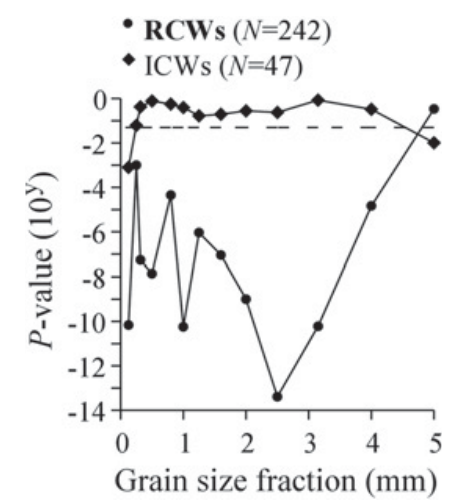

Fig. 3. Significance of correlations between grain availability and use (dry mass $0.06 \mathrm{~m}^{-2}$ ) of grain fractions across all taxa and sites for RCWs and ICWs (if samples had $\geq 10$ pupae per group). The horizontal broken line indicates $P=0.05$ (note that availability and use of all fractions with $P<0.05$ were positively correlated here and in Figs. 4 and 6).

based on $92 \%$ of RCW and $63 \%$ of ICW pupae, as the latter were in distinctly fewer samples abundant (Fig. 3). Grain mass availability and use by RCWs was significantly correlated in all but one grain fraction (Fig. 3). The insignificant correlation occurred in the fraction $5-10 \mathrm{~mm}$, which had the highest mass availability among all fractions (see above). However, of this as well as of the other fractions, the RCWs used more mass of a given fraction if its availability was higher. The only grain fractions with significant correlations between mass availability and use by ICWs were the smallest $(0.125-0.25)$ and the largest $(5-10 \mathrm{~mm})$ ones included in the analysis (Fig. 3). Given that these fractions were very rarely used by ICW taxa (see Fig. 2), the positive correlations between availability and use of these fractions were spurious and ICW results will be omitted from subsequent sections.

\section{RCWs across all taxa at different sites}

Reducing the samples to those having $\geq 10$ pupae of RCWs, the number of samples available per site varied considerably, as RCWs were sometimes only in relatively few samples abundant (Fig. 4). Correspondingly, the percentage of pupae representing each site in the analyses here varied among sites from 22\% (Cuisance05), 73\% (Bez), 82\% (Cusancin), 86\% (Cuisance03), 95\% (Furan), to $99 \%$ (Loire). The abundance of available samples and pupae was mirrored in the significance levels of correlations between grain mass availability and use of the individual grain fractions (positively correlated if $P<0.05$ ). Most significant were many of the correlations in the Furan (96 samples), intermediately significant were correlations in Loire (49 samples) and Cuisance03 (48 samples), whereas correlations at the remaining three sites (5-28 samples) were at best marginally significant for a few grain fractions. In the Furan, the most significant correlations between mass availability and use occurred in the fractions 2-4 mm (Fig. 4). In Cuisance03 and Loire, the significance differences among grain fractions were less pronounced.

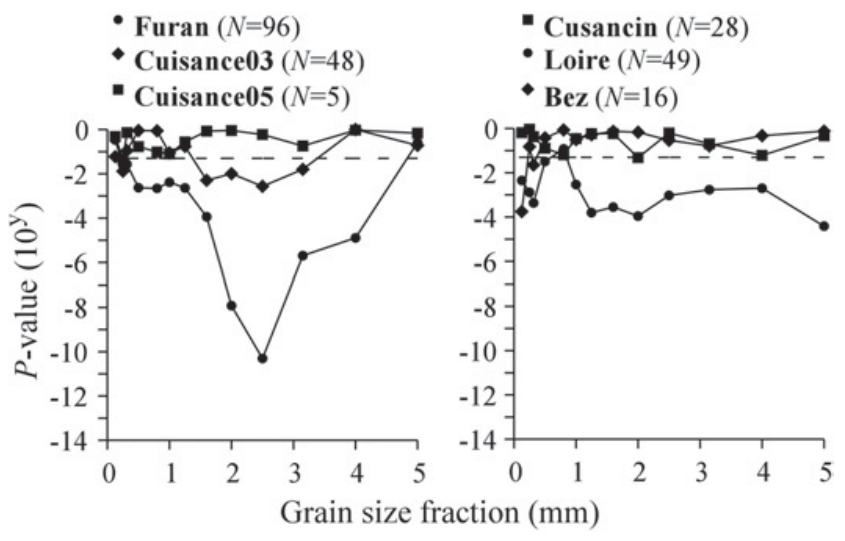

Fig. 4. Significance of correlations between grain availability and use of grain fractions across all RCW taxa for sites. See Figure 3 for further details.

The most significant correlations between mass availability and use occurred in the fractions $1.6-4 \mathrm{~mm}$ in the Cuisance 03 and in the fractions $1.25-2.5 \mathrm{~mm}$ and $5-10 \mathrm{~mm}$ in the Loire (Fig. 4).

Corresponding to the highest significance levels of the correlations between mass availability and use in Furan and Cuisance03, the relative grain mass use was highest in the fractions $2-4 \mathrm{~mm}$ in the Furan and in the fractions 1.6-4 mm in the Cuisance03 (Fig. 5). In the Loire, the relative mass use was only highest for the intermediate grain size fractions $1.25-2.5 \mathrm{~mm}$, whereas the other fraction with a highly significant correlation between mass availability and use $(5-10 \mathrm{~mm})$ was not abundantly used by RCWs (Fig. 5). On average, relative mass use of the dominating size fractions in the cases ranged between $\sim 15-25 \%$. Compared to peaks in relative grain mass use in Furan, Cuisance03, and Loire, the other three sites had similarly high peaks in the relative mass use of a few size fractions (Fig. 5). This latter pattern suggested that lacking or low significance of correlations between grain mass availability and use in Cusancin, Cuisance05, and Bez were primarily caused by the low sample size available for these sites.

\section{Abundant RCW taxa}

Given that abundant RCW taxa in the Furan (H. siltalai and Rhyacophila) have been analyzed in detail elsewhere (Statzner et al., 2005), I limit this section to RCW taxa that were abundant at the other sites. As for the RCWs at the sites, the number of samples available per abundant RCW taxon varied considerably (Fig. 6) and the percentage of pupae representing each taxon in the analyses varied again correspondingly from $47 \%$ ( $H$. incognita), $79 \% \quad(G$. bifidum $), 80 \% \quad(H$. exocellata), to $94 \%$ (H. contubernalis and Rhyacophila). The abundance of available samples and pupae was less clearly mirrored in the significance levels of correlations between grain mass availability and use (positively correlated if $P<0.05$ ) of the individual grain fractions than for the overall RCWs at the sites. Most significant were many of the correlations 

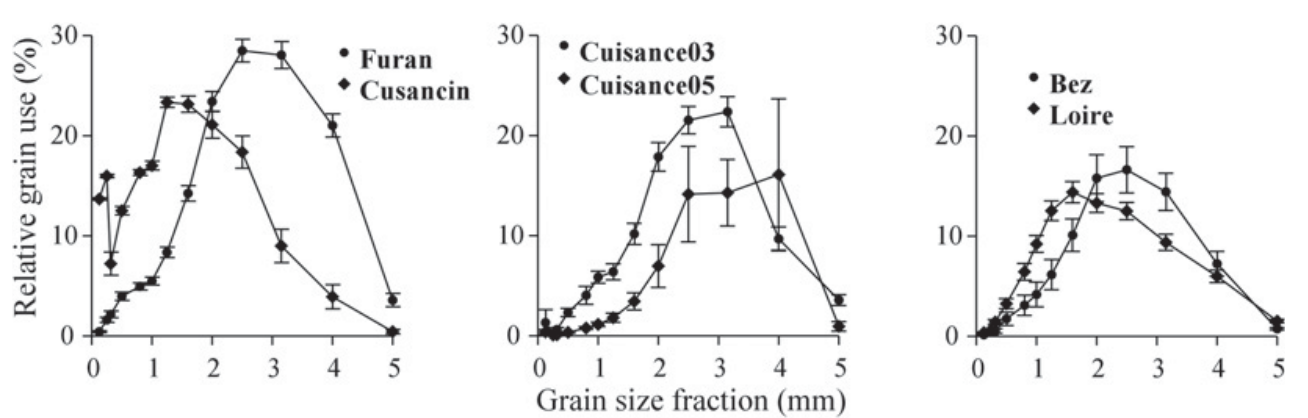

Fig. 5. Relative grain mass use (as percentage of dry mass availability $0.06 \mathrm{~m}^{-2}$ ) of grain fractions across all RCW taxa for sites (if samples had $\geq 10$ pupae). See Figure 4 for sample sizes.

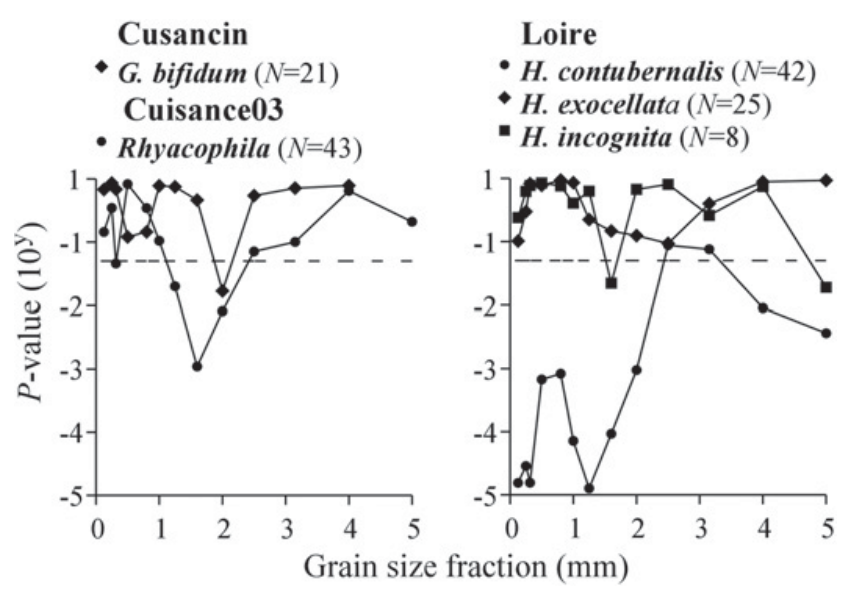

Fig. 6. Significance of correlations between grain availability and use of grain fractions for five abundant ( $\geq 10$ pupae per sample) RCW taxa. See Figure 3 for further details.

in $H$. contubernalis (42 samples) and intermediately significant were correlations in Rhyacophila (43 samples), whereas correlations in the remaining three species (8-25 samples) were at best marginally significant for a few grain fractions (Fig. 6).

In $H$. contubernalis, the most significant correlations between mass availability and use occurred in the fractions 0.125-0.5 mm and 1-2 mm (Fig. 6). In Rhyacophila, the most significant correlations between mass availability and use occurred in the fractions $1.25-2.5 \mathrm{~mm}$. In G. bifidum, one significant correlation occurred in the fraction 2-2.5 $\mathrm{mm}$ and in $H$. incognita, this occurred twice in the fractions $1.25-1.6 \mathrm{~mm}$ and $5-10 \mathrm{~mm}$. Grain size use by $H$. exocellata was never significantly correlated to grain availability (Fig. 6).

In contrast to overall RCW patterns at the sites, there was no clear correspondence in relatively high significant levels of the correlations between mass availability and use in particular grain fractions and the relative grain mass use of these fractions by the abundant RCW taxa (Fig. 7). At best, grain size fractions with a high correlation between availability and use were near the size of fractions with a high relative use by the abundant taxa. The peak relative use of grain fractions by G. bifidum and Rhyacophila was $\sim 20 \%$ and thus near that of all RCWs at their respective sites (Cusancin and Cuisance03). Likewise, the overall patterns of relative grain size use by $G$. bifidum and Rhyacophila resembled that of all RCWs in Cusancin and Cuisance03, respectively (compare Figs. 7 and 5). In contrast, the three Hydropsyche species in the Loire contributed individually only about one third to the overall peak relative use by $\mathrm{RCWs}$ at the site, as each of them had a peak relative use of $\sim 7 \%$ (Fig. 7 ).

For analyses of grain availability and case architecture of abundant RCW taxa, I transformed the grain data into availability and use per pupa. In G. bifidum, the relation between mean available and used mass per pupa in the 2-2.5 $\mathrm{mm}$ fraction was by far the most significant among all individual fractions assessed here. In this fraction, use increased logarithmically with availability (Fig. 8; note the $x$-axis scale). In contrast, use increased linearly with availability in the $0.5-0.8 \mathrm{~mm}$ fraction, and the availability of this fraction increased linearly with the availability of the fraction $2-2.5 \mathrm{~mm}(P=0.002)$. However, per capita uses of these two fractions by $G$. bifidum were not significantly related $(P=0.631)$. Finally, use of the fraction $0.8-1 \mathrm{~mm}$ increased linearly with use of the neighboring fraction $0.5-0.8 \mathrm{~mm}$ by this species, and availabilities of these two neighboring grain fractions were positively related $\left(P<10^{-14}\right.$; note that relations between availabilities of neighboring grain fractions reported in this subsection were always positive and similarly significant). In Rhyacophila, use of the fraction 1.6-2 mm increased linearly with its availability and use (and availability) of the fraction $1.25-1.6 \mathrm{~mm}$ increased linearly with use (and availability) of the neighboring fraction 1.6-2 mm (Fig. 8).

Among the Hydropsyche species of the Loire, use of the fraction $5-10 \mathrm{~mm}$ by $H$. incognita and $H$. contubernalis was significantly increasing in a linear way with the availability of this fraction (Fig. 8). In H. contubernalis, use (and availability) of the fraction $4-5 \mathrm{~mm}$ increased linearly with use (and availability) of the neighboring fraction 5-10 mm. Furthermore, use of the fraction 1.25-1.6 mm by this species was linearly increasing with its availability, and the availability of this fraction increased linearly with that of the fraction $5-10 \mathrm{~mm}\left(P<10^{-3}\right)$. However, as in $G$. bifidum, per capita uses of these two fractions were again not significantly related $(P=0.187)$. In addition, use (and availability) of the fraction $1.25-1.6 \mathrm{~mm}$ were also positively related with use (and availability) of the neighboring fraction 1.6-2 mm (Fig. 8). Finally, uses of 

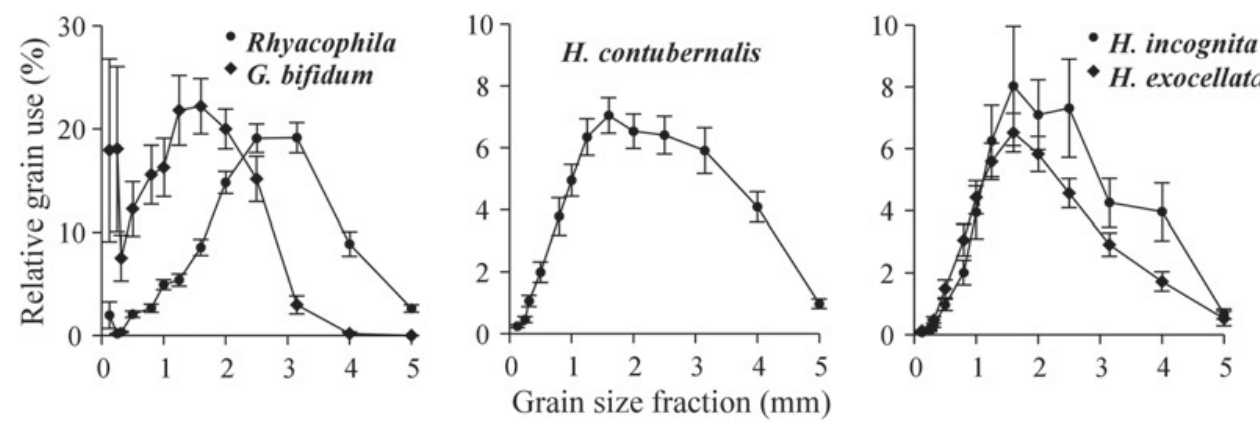

Fig. 7. Relative grain mass use (as percentage of dry mass availability $0.06 \mathrm{~m}^{-2}$ ) of grain fractions for five abundant ( $\geq 10$ pupae per sample) RCW taxa. Note the differently scaled $y$-axes and see Figure 6 for sample sizes and sites of the taxa.

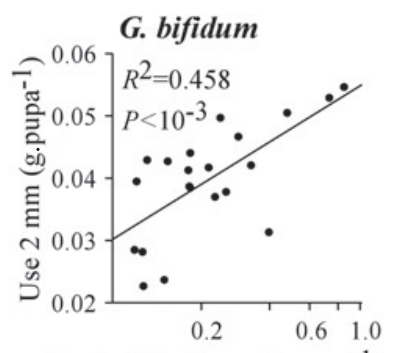

Availability $2 \mathrm{~mm}\left(\mathrm{~g} . \mathrm{pupa}^{-1}\right)$

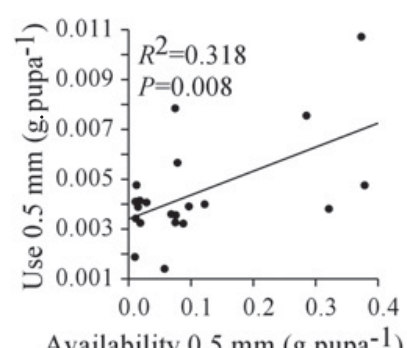

Availability $0.5 \mathrm{~mm}\left(\mathrm{~g} \cdot \mathrm{pupa}^{-1}\right)$

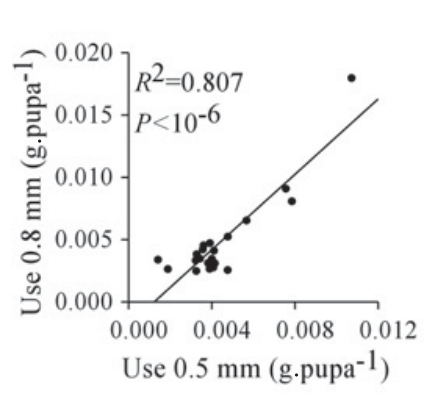

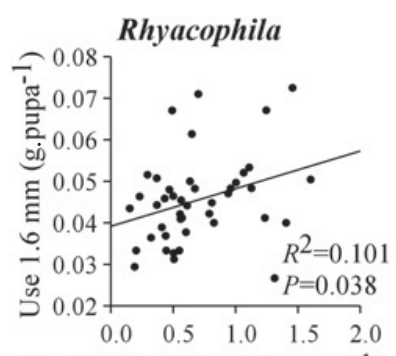

Availability $1.6 \mathrm{~mm}\left(\mathrm{~g} \cdot \mathrm{pupa}^{-1}\right)$

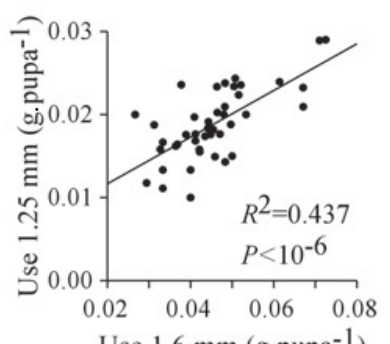

Use $1.6 \mathrm{~mm}\left(\right.$ g.pupa $\left.{ }^{-1}\right)$

\section{H. incognita}

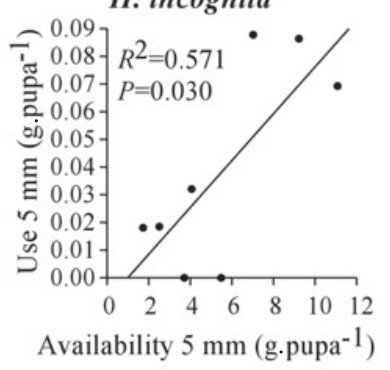

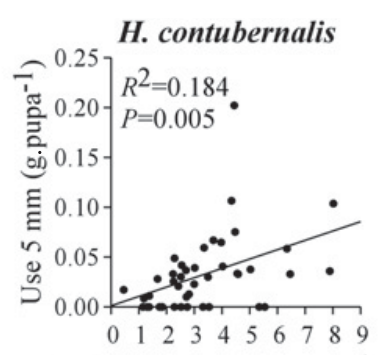

Availability 5 mm (g.pupa $\left.{ }^{-1}\right)$

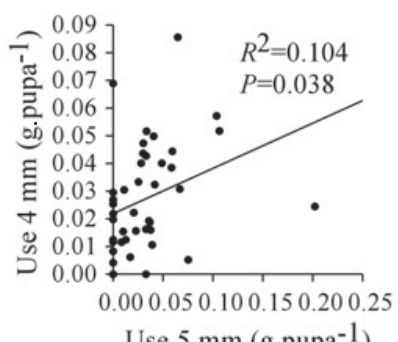

Use $5 \mathrm{~mm}$ (g.pupa $\left.{ }^{-1}\right)$

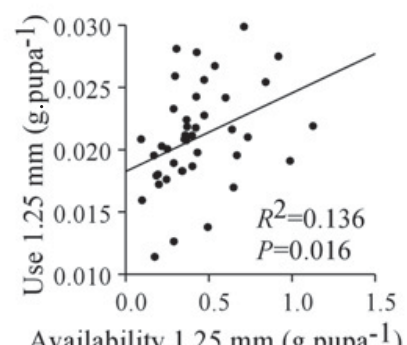

Availability $1.25 \mathrm{~mm}$ (g.pupa $\left.{ }^{-1}\right)$

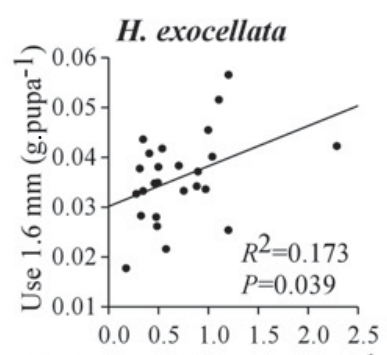

Availability $1.6 \mathrm{~mm}\left(\mathrm{~g} . \mathrm{pupa}^{-1}\right)$
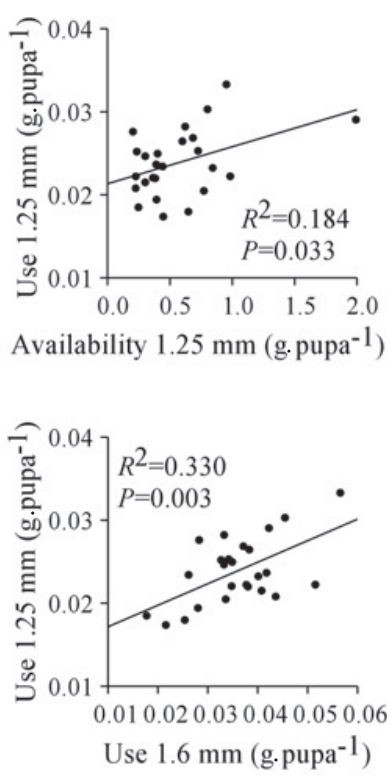
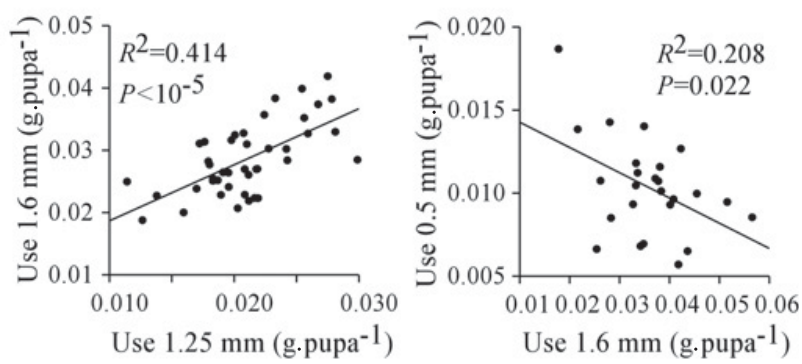

Fig. 8. Relations between per capita grain availability and use and associated uses of other grain fractions for five abundant ( $\geq 10$ pupae per sample) RCW taxa. Note the differently scaled axes and see Figure 6 for sample sizes and sites of the taxa. 


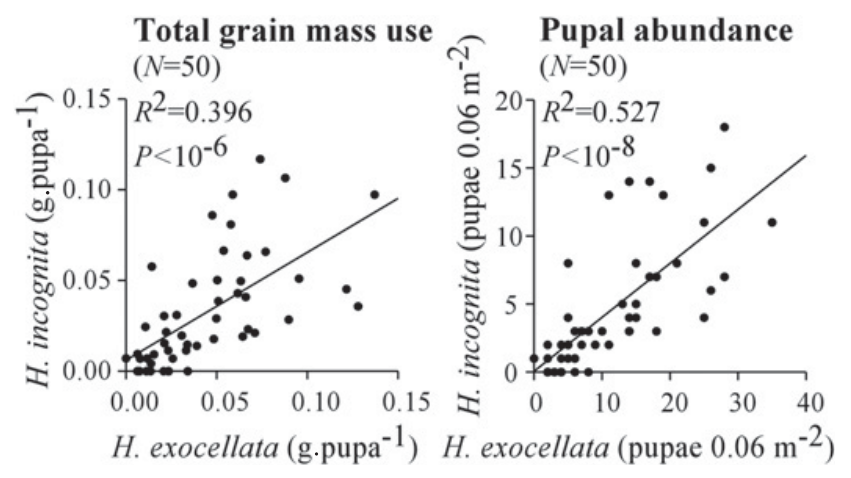

Fig. 9. Relations of per capita mass use and abundance between two Hydropsyche species in the Loire for all samples.

the fractions $1.6-2 \mathrm{~mm}$ and $1.25-1.6 \mathrm{~mm}$ by $H$. exocellata were linearly increasing with respective fraction availabilities, and uses (and availabilities) of these neighboring fractions were also positively related. In addition, use of the fraction $0.5-0.8 \mathrm{~mm}$ decreased linearly with use of the fraction 1.6-2 mm (Fig. 8), although availabilities of these two fractions were positively related in a linear way $\left(P<10^{-9}\right)$ and use and availability of fraction $0.5-0.8 \mathrm{~mm}$ were not related $(P=0.678)$.

\section{Indicators of potential competition for grain resources among co-existing Hydropsyche species}

The Loire site was the only one studied where more than one Hydropsyche species were relatively abundant (see Table 1 above). Indicators of potential competition among these species at this site were significantly related between $H$. incognita and $H$. exocellata (Fig. 9). However, total grain mass use and pupal abundance of these species increased linearly across all 50 samples, indicating no competition between them. In comparison, total grain mass use by $H$. contubernalis was not related to that of the other two species ( $P$-values: 0.795 and 0.902$)$ and pupal abundance of the former only tended to increase with that of the two latter ( $P$-values: 0.097 and 0.156$)$.

Furthermore, overall grain size use across all 50 samples of fractions having a significantly positive relation between per capita use and availability at high pupal densities were never significantly related when comparing the respective species. For the fraction $5-10 \mathrm{~mm}$ and $H$. incognita and $H$. contubernalis, the significance of the relation between uses by these two species was $P=0.898$. Likewise, for the fraction $1.25-1.6 \mathrm{~mm}$ and $H$. contubernalis and $H$. exocellata, the use-use relation was not significant $(P=0.062)$ and tended to be positive, not negative.

\section{Discussion}

\section{Overall grain availability and overall pupal case architecture}

With the exception of the Cusancin, the cumulative mass curves of the fractions $<5 \mathrm{~mm}$ were relatively similar at the study sites. This similarity reflected the similarity of physical conditions assessed across the sites. Firstly, sampling was limited to the upper sediment layer where caddisfly pupae were found. Secondly, sampling was stratified to cobbles in riffle habitats with relatively similar bottom shear stress. The reason for the differences of the sediments at the Cusancin site from those at the other sites related presumably to the relatively short site distance of the former from its source and the relatively high proportion of forest cover on its bank and in its catchment. All these factors are potential causes of low fine sediment supply from the catchment upstream of a given site (Mangelsdorf and Scheurmann, 1980; Gurnell et al., 2009; Tomer et al., 2009). Thus, the relative rarity of fine sediments in the Cusancin should have primarily been the result of low fine sediment supply from the catchment.

This overall lack of smaller grains in the Cusancin was variously reflected in the overall architecture of the pupal cases if compared to that in the other rivers. The only taxa that were seemingly constrained by this lack were the larger RCWs H. dinarica and Rhyacophila, which used on average more larger grains in the Cunsancin than elsewhere they occurred. This possible grain constraint was also mirrored in the relative low abundance of these larger RCWs in the Cusancin (on average, 1.5 pupae $0.06 \mathrm{~m}^{-2}$ ) if compared to the other sites (range of average abundance there: 4.7-35.5 pupae $0.06 \mathrm{~m}^{-2}$ ). Assuming that $H$. dinarica in the Cusancin would have the same pupal density as the Hydropsyche species in the Loire and the $H$. dinarica cases in the Cusancin would have the same overall architecture as illustrated in Figure 2, $\mathrm{H}$. dinarica would have to use $84 \%$ of the available grain mass in the fractions $<5 \mathrm{~mm}$ and $146 \%$ of the available grain mass in the fraction $3.15-4 \mathrm{~mm}$, which was simply impossible in the Cusancin. Thus, data on the larger RCWs supported the idea that the availability of the preferred mineral case material is a limiting factor for caddisflies at larger scales such as river or habitat types (e.g., Hanna, 1961; Tolkamp, 1980; De Moor, 2005; Takao et al., 2008), whereas data on the other taxa provided no support for this idea. Further support for this idea was provided by a study on a larger RCW (H. siltalai) in a southwestern French river, which shifts the habitat use from coarse bottom/high velocity to finer bottom substrates and lower velocities when coming into its final larval instar (i.e., the builder of the pupal case) (Hanquet et al., 2004).

\section{Local grain availability and grain quantities in pupal cases}

Across all taxa and sites, grain mass availability and use by RCWs was significantly correlated in all but one size fraction, whereas the significant correlations (in two fractions) of availability and use by ICWs were spurious. Furthermore, across all taxa and sites, the use of all grain size fractions by RCWs increased with their availability. Thus, these patterns supported the first hypothesis to be tested here: grain quantities in the pupal cases of RCWs but not of ICWs increased with local grain availability 
when pupae were abundant. I have to acknowledge, however, that the test of this first hypothesis was somewhat biased as the overall abundance (see Table 1) and the number of samples with abundant pupae (see Fig. 3) differed considerably between RCWs and ICWs.

At the three sites having the highest sample numbers with abundant pupae, grain availability and use by RCWs correlated significantly in several size fractions, which were typically those with the highest mean values of the relative grain use ( $\sim 15-25 \%$ of the available mass). These coincidences of high significance levels of correlations between mass availability and use with those of high relative uses of the corresponding grain size fractions suggested that certain fractions were a limited resource for pupal casebuilding RCWs in Furan, Cuisance03, and Loire. Given that grain availability was certainly overestimated by the applied sampling method (see above), the real mean values of the high relative grain uses should have been even higher. Thus, for the three sites having abundant samples with high pupal case densities available, the observed patterns supported the idea that grain quantities in $\mathrm{RCW}$ pupal cases increase with local grain availability in the preferably used fractions because these fractions are locally limited resources.

However, this relatively clear support across RCW taxa at each of the three sites with abundant samples was not as equivocally supported by analyses of the individual, abundant RCW taxa. Although dominating RCW taxa at a given site also dominated the relative grain size use pattern at their respective site, there were no clear correspondences in the significance of correlations between grain size availability and use and the relative uses of size fractions.

\section{Local grain availability and case architecture of abundant RCW taxa}

For each of the five abundant RCW taxa, I found at least one grain fraction that had a significantly positive relation between per capita availability and use, which supported the second hypothesis to be tested here: local case architecture was affected by local per capita grain size availability when pupae were abundant. In $H$. incognita and $H$. contubernalis, per capita use of the largest grains (5-10 $\mathrm{mm})$ increased with grain availability, although the pupal case builders of the two species used on average only $\sim 2 \%$ of the available grain mass of this fraction in the Loire. This low relative use of the fraction $5-10 \mathrm{~mm}$ by these Hydropsyche species suggested that the positive relations between per capita availability and use were spurious. Alternatively, the builders of these cases could have used primarily grains from the lower end of the grain size range of the entire fraction (e.g., 5-6 mm) that, in terms of mass availability, represented a relatively small part of the entire fraction.

Except in $H$. incognita, per capita use increased significantly with availability in one or two of the fractions in the grain size range $1.25-2.5 \mathrm{~mm}$ in the other four abundant RCW taxa. In Rhyacophila, this was observed for one fraction in this size range. In contrast, in
$H$. contubernalis, the significant availability-use relation (fraction 1.25-1.6 $\mathrm{mm}$ ) in this size range was the second fraction for which this was observed (as for the fraction 5-10 mm). Given that per capita availabilities of these two fractions were significantly related but not their uses, this suggested that $H$. contubernalis had a case architecture with a varying mixture of grains in the size $1.25-1.6 \mathrm{~mm}$ and $5-10 \mathrm{~mm}$. In addition to one fraction $(2-2.5 \mathrm{~mm})$ in the size range $1.25-2.5 \mathrm{~mm}$, use by G. bifidum of the fraction $0.5-0.8 \mathrm{~mm}$ increased also significantly with its availability. Given that per capita availabilities of these two fractions were significantly related but not their uses, this suggested that G. bifidum, similarly to $H$. contubernalis, had a case architecture with a varying mixture of grains in the size $0.5-0.8 \mathrm{~mm}$ and $2-2.5 \mathrm{~mm}$.

In comparison, the two significant relations between per capita availability and use observed in $H$. exocellata occurred in neighboring size fractions $(1.25-1.6 \mathrm{~mm}$ and 1.6-2 mm). Given that uses of these two neighboring fractions by the species were positively related, this suggested that $H$. exocellata used preferably grains in the size range $1.25-2 \mathrm{~mm}$ (indeed, per capita availability and use of grains in this size range were more significantly related $\left(R^{2}=0.229, P=0.013\right)$ than in each individual fraction). Interestingly, using more grains in the fraction 1.6-2 $\mathrm{mm}, H$. exocellata used fewer grains in the fraction $0.5-0.8 \mathrm{~mm}$, which was an unlimited resource that was increasingly available with increasing availability of the fraction $1.6-2 \mathrm{~mm}$. This pattern suggested that the resource limitation of a preferred grain size produced a cascade effect towards another grain fraction that was an unlimited resource, comparable to patterns previously reported for $H$. siltalai (Statzner et al., 2005).

In four of the five abundant RCW taxa, the significant increase of per capita availability and use of a given grain fraction was associated with a significantly increased per capita use of a neighboring grain size fraction. Thus, contrasting to laboratory results (Hanna, 1961; Tolkamp, 1980), shortage of the seemingly preferred mineral grain size was not compensated by switching to grain sizes near the upper or lower limit of the preferred grain size range in this and a previous (Statzner et al., 2005) field study. This difference related to differences between the physical conditions studied in the laboratory and the field. In the former, the grain availability alone was experimentally manipulated. In the field, however, the similarity of the locally prevailing shear stress conditions causes similarity of locally available neighboring grain size fractions, i.e., grain availability of neighboring size fractions is either relatively high or relatively low (Statzner et al., 2005; this study, as correlations between grain size availabilities of neighboring fractions were positive and highly significant).

\section{Indicators of potential competition for grain resources among co-existing Hydropsyche species}

Unexpectedly, neither overall grain use, abundance of pupae, nor uses of grain fractions that were limited 
by grain availabilities provided indications for interspecific competition among the three Hydropsyche species in the Loire. This result is even more surprising when considering the known details of the biology in this genus. The competitive superiority in fights between larvae that simultaneously build pupal cases on adjacent locations reported by Mogel et al. (1985) should increase linearly with larval head length (Pierrot, 1984). Losers of such fights typically escape by drift, which is viewed as one key factor for observed interspecific differences in water velocity and microhabitat preferences, life cycles, and diets (Schuhmacher, 1970; Hildrew and Edington, 1979). Given that the mean head length of last instar larvae from the Loire separated H. incognita $(1.01 \mathrm{~mm})$ from $H$. exocellata $(0.82 \mathrm{~mm})$ and $H$. contubernalis $(0.78 \mathrm{~mm})$ (Statzner et al., 2010), one would expect that at least the competitive superiority of the distinctly larger $H$. incognita over the two other species would have been mirrored in resource use and abundance. Instead, however, I found no relation in resource use and abundance between $H$. incognita and $H$. contubernalis and, even more surprisingly, I found positive relations between these variables when analyzing $H$. incognita with H. exocellata.

Two major reasons may be responsible for the lacking support for competition among congeneric or less related RCW taxa using similar grain sizes in a river riffle. Firstly, the size of the benthos area sampled was perhaps too coarse to detect the segregation of species into microhabitats of the size inferior to that of cobble (e.g., top vs. bottom of a stone; Hildrew and Edington, 1979). Secondly, perhaps to avoid competition, pupal casebuilding periods can be temporally segregated (at least in parts), which has been reported for co-existing species in the genera Hydropsyche and Rhyacophila (Hildrew and Edington, 1979; Céréghino et al., 1997; Sangpradub et al., 1999). In combination, these two reasons potentially created so much noise that the signal of an actually existing competition among co-existing RCWs could not be detected.

\section{Conclusions}

Testing my two hypotheses through a field survey, I found supporting evidence for both of them at the local scale of samples. In addition, I found support for the idea that at larger scales such as river or habitat types, mineral grains may be a limited resource for larger RCW caddisflies building pupal cases with them. Providing such evidence in support for limitations in a seemingly overabundant resource used by stream-dwelling caddisflies to build mineral cases in the natural environment has been very rare in the past (Dudgeon, 1990; Statzner et al., 2005). In contrast, I found no support for interspecific competition for grain resources, which presumably occurred at smaller spatial scales or were avoided at larger temporal scales than those considered here.

Obviously, the constraints interfering in this type of resource limitations were quite subtle so that its discovery required a careful study design as well as some luck. Firstly, including so far too often ignored pupal cases of RCWs as study object was a prerequisite for the demonstration of resource limitations, as these cases are those that should depend the most of all case types on local grain availability. Secondly, I used preliminary results communicated by Statzner et al. (2005) to select physical conditions to be sampled as well as a sample size that buffered against intraspecific case variation within samples. Thirdly, the patterns reported here were seemingly not obscured by major flood disturbances, although the time passed between case building and assessment of grain availability was potentially a problem of this study. Thus, the overall framework of this study was favorable for the discovery of rather diverse responses of case-building caddisflies to resource limitations of mineral grains. This diversity included (1) a simple positive relation between grain availability and use of one size fraction; (2) a simple positive relation between grain availability and use of one size fraction and associated use of a neighboring size fraction; (3) simple positive relations between grain availability and use of two fractions of distinctly different sizes and associated use of one or two neighboring size fractions; and (4) simple positive relations between grain availability and use of two neighboring size fractions and more complicated cascade effects (resource limitation of a preferred size fraction affected the use of a rather different size fraction that was an unlimited resource; for another example on this type in Hydropsyche see Statzner et al. (2005)).

Not surprisingly, such a diversity in response patterns required analyzing only samples with high pupal abundance and even then the data scattered considerably. Ignoring samples with low pupal abundance resulted sometimes in considerable loss of sample size. This loss, however, did not result in an equivalent loss of the population size of the RCWs included in the analyses, as $92 \%$ of them at all sites, $22-99 \%$ of them at the individual sites, and $47-94 \%$ of the abundant RCW taxa were retained. Thus, the results are relevant for large parts of natural $\mathrm{RCW}$ populations, and this relevance is obvious when grain use per location or site increases with grain availability.

Concerning the biological relevance of the more subtle responses in case architecture, it would require welldesigned laboratory experiments to provide solid evidence (e.g., Nogueira et al., 2004). Currently, I can only speculate that the so far observed minor changes in per capita grain size uses would make no significant differences for the costs of silk production for RCW specimens. Firstly, larvae that have finished building their pupal case may have their silk glands tightly filled with secretion (e.g., in Hydropsyche; Haller, 1948). Secondly, the example of Hydropsyche larvae illustrates that caddisflies use plenty of silk through their entire life for safety threads when moving, or for frequently renewed larval retreats and filter nets (Sattler, 1958; Schuhmacher, 1970; Statzner et al., 1999). Thirdly, forcing caddisflies to use plenty of silk prior to pupation (by experimentally manipulating case construction and thereby silk expenditure) causes only minor (although significant) decreases in the mass of 
the emerging adults in comparison to control groups (Stevens et al., 1999, 2000). Therefore, changes in silk use in relation to the observed changes in case architecture of the pupal cases should be a marginal quantity in the overall silk budget of these RCWs. In contrast, differences in case architectures at the lowest and highest availability of preferred grain fractions could have consequences for the case stability (e.g., the resistance of the case to break if floods move coarser bottom material), as Hydropsyche pupal cases with coarser grains resisted to higher crushing forces than cases with finer grains (Statzner et al., 2009).

Expanding the study by Statzner et al. (2005) to more running water types and species enables safer generalizations of a topic that interested aquatic ecologists since long but was not well supported by field evidence for caddisflies and other aquatic invertebrates building with mineral grains. Obviously, increasing flow facilitates respiration but also erodes mineral grains of increasing size, until the grains become so large that they cannot be used by building invertebrates, except for the attachment of the building. This conflict of resource requirements is extreme for invertebrates that are RCWs needing simultaneously at their building location fine mineral grains for their building, coarse grains to attach their building, and high oxygen renewal rates, i.e., for RCWs among caddisflies, midges, and moths that attach their case or tube to stones in rapidly flowing stream riffles, but also for lacustrine and marine RCW invertebrates that attach their buildings to rocks on wave exposed shores. In addition, water currents in natural environments simultaneously create a shortage in mineral grain sizes that are in or near the grain size range preferably used by an invertebrate builder. Thus, in contrast to laboratory conditions, switching to grain sizes neighboring the preferred grain size range is difficult in natural habitats. The diverse responses to this problem seen in the few so far studied caddisfly taxa suggest that evolution found many ways to adapt to this type of resource limitation, similarly to substantial response variability to resource limitations in lake zooplankton (Pereira and Gonçalves, 2008). Thus, although the basic principle of resource limitation for plants and animals was recognized in the pioneer age of ecology (e.g., Liebig, 1840; Semper, 1880), there is still much to discover by research on subtle details.

Acknowledgements. I thank Marie-Françoise Arens, Sylvain Dolédec, Gisèle Journaux, Emmanuel Malet, Sylvie Mérigoux, and Jean-Michel Olivier for help during the fieldwork, and particularly Marie-Noëlle Truchet, who helped to process and to sort the samples, fractioned them, and determined the dry weight of thousands of grain fractions. I also thank two anonymous referees for comments on the manuscript.

\section{References}

Abdoli A., Pont D. and Sagnes P., 2005. Influence of female age, body size and environmental conditions on annual egg production of the bullhead. J. Fish Biol., 67, 1327-1341.
Becker G., 2001. Larval size, case construction and crawling velocity at different substratum roughness in three scraping caddis larvae. Arch. Hydrobiol., 151, 317-334.

Begon M., Harper J.L. and Townsend C.R., 1986. Ecology, Blackwell, Oxford, 876 p.

Bohle H.-W. and Fischer M., 1983. Struktur und Entstehung der Larven- und Puppengehäuse einiger Glossosomatidae und Rhyacophilidae, inbesondere bei Synagapetus iridipennis (Trichoptera: Rhyacophiloidea). Entomol. Gener., 9, 17-34.

Buitenhuis E.T., Timmermans K.R. and De Baar H.J.W., 2003. Zinc-bicarbonate colimitation of Emiliania huxleyi. Limnol. Oceanogr., 48, 1575-1582.

Céréghino R., Boutet T. and Lavandier P., 1997. Abundance, biomass, life history and growth of six Trichoptera species under natural and hydropeaking conditions with hypolimnetic release in a Pyrenean stream. Arch. Hydrobiol., 138, 307-328.

De Moor F.C., 2005. Variation in case construction of Trichoptera larvae in southern Africa. Proc. 11th Int. Symp. Trichopt., 2003, 107-114.

Dudgeon D., 1990. Functional significance of selection of particles and their use by aquatic animals in the construction of external structures. In: Wotton R.S. (ed.), The biology of particles in aquatic systems, CRC, Boca Raton, FL, 263-288.

Elliott J.M., 1971. Upstream movements of benthic invertebrates in a lake district stream. J. Anim. Ecol., 40, 235-252.

González M.A., Iglesias J.C. and Cobo F., 1989. Description de la larve et considérations sur l'habitat, la biologie et la répartition de Thremma tellae (Trichoptera: Uenoidea: Thremmatinae). Ann. Limnol., 25, 237-241.

Gorter F.J., 1931. Köcherbauversuche an Trichopterenlarven. Z. Morph. Ökol. Tiere, 20, 443-532.

Gurnell A., Surian N. and Zanoni L., 2009. Multi-thread river channels: a perspective on changing European alpine river systems. Aquat. Sci., 71, 253-265.

Haller P.H., 1948. Morphologische, biologische und histologische Beiträge zur Kenntnis der Metamorphose der Trichopteren (Hydropsyche). Mitt. Schweiz. Entomol. Ges., 21, 301-359.

Hanna H.H., 1961. Selection of materials for case-building by larvae of caddis flies (Trichoptera). Proc. R. Entomol. Soc. Lond. (A), 36, 37-47.

Hanquet D., Legalle M., Garbage S. and Céréghino R., 2004. Ontogenetic microhabitat shifts in stream invertebrates with different biological traits. Arch. Hydrobiol., 160, 329-346.

Hansell M.H., 1973. Improvement and termination of house building in the caddis larva Lepidostoma hirtum Curtis. Behaviour, 46, 141-153.

Hansell M.H., 1974. The house building of caddis larvae: a source of projects for schools. J. Biol. Educat., 8, 88-98.

Higler B., 2005. De nederlandse kokerjufferlarven, KNNV Uitgeverij, Utrecht, 158 p.

Hildrew A.G. and Edington J.M., 1979. Factors facilitating the coexistence of hydropsychid caddis larvae (Trichoptera) in the same river system. J. Anim. Ecol., 48, 557-576.

Hynes H.B.N., 1970. The ecology of running waters, Liverpool University Press, Liverpool, 555 p.

Ivol J.-M., Guinand B., Richoux P. and Tachet H., 1997. Longitudinal changes in Trichoptera and Coleoptera assemblages and environmental conditions in the Loire River (France). Arch. Hydrobiol., 138, 525-557. 
Jackson J.K., McElravy E.P. and Resh V.H., 1999. Long-term movements of self-marked caddisfly larvae (Trichoptera: Sericostomatidae) in a California coastal mountain stream. Freshw. Biol., 42, 525-536.

Johnson H. and Duijker H., 1993. Atlas der französischen Weine (4th edn.), Hallwag, Bern, 279 p.

Lepneva S.G., 1970. Larvae and pupae of Annulipalpia, Israel Program for Scientific Translations, Jerusalem, 638 p.

Lepneva S.G., 1971. Larvae and pupae of Integripalpia, Israel Program for Scientific Translations, Jerusalem, 560 p.

Liebig J., 1840. Die organische Chemie in ihrer Anwendung auf Agricultur und Physiologie, Vieweg, Braunschweig, 353 p.

Mackay R.J., 1977. Behavior of Pycnopsyche (Trichoptera: Limnephilidae) on mineral substrates in laboratory streams. Ecology, 58, 191-195.

Mackay R.J. and Wiggins G.B., 1979. Ecological diversity in Trichoptera. Annu. Rev. Entomol., 24, 185-208.

Malicky H., 1983. Atlas of European Trichoptera, Junk, The Hague, 298 p.

Malicky H., 2000. Which caddis larvae construct a new case for pupation? Braueria, 27, 19-20.

Mangelsdorf J. and Scheurmann K., 1980. Flußmorphologie, Oldenbourg, München, $262 \mathrm{p}$.

Mogel R., Rieder N. and Statzner B., 1985. Ein Gerät zur Freilandbeobachtung des nächtlichen Verhaltens von benthischen Bachtieren, mit Befunden aus der Gattung Hydropsyche (Trichoptera, Insecta). Carolinea, 42, 121-128.

Neu P.J. and Tobias W., 2004. The identification of the German Hydropsychidae (Insecta: Trichoptera). Lauterbornia, 51, 1-68.

Newbury R.W. and Gaboury M.N., 1993. Stream analysis and fish habitat design, Newbury Hydraulics, Gibsons, BC, $262 \mathrm{p}$.

Nogueira A.J.A., Baird D.J. and Soares A.M.V.M., 2004. Testing physiologically-based resource allocation rules in laboratory experiments with Daphnia magna Straus. Ann. Limnol. - Int. J. Lim., 40, 257-267.

Okano J., Kikuchi E. and Sasaki O., 2010. The role of particle surface texture on case material selection and silk lining in caddis flies. Behav. Ecol., 21, 826-835.

Otto C., 2000. Cost and benefit from shield cases in caddis larvae. Hydrobiologia, 436, 35-40.

Otto C. and Johansson A., 1995. Why do some caddis larvae in running waters construct heavy, bulky cases? Anim. Behav., 49, 473-478.

Pereira J.L. and Gonçalves F., 2008. Daphnia fitness over a food gradient: is body size the single trait predicting exploitative ability? Ann. Limnol. - Int. J. Lim., 44, 169-179.

Pierrot J.-P., 1984. Étude expérimentale de la niche écologique larvaire de quelques espèces d'Hydropsyche (Trichoptera, Hydropsychidae), Ph.D. thesis, University of Lyon 1, 251 p.

Podgornyi K.A. and Nepomnyashchikh V.A., 1999. Effects of behavioral variability on optimization of caddis fly (Chaetopteryx villosa) larvae behavior. Adv. Curr. Biol., 119, 218-222 (in Russian, with English abstract).

Rost B., Riebesell U., Burkhardt S. and Sültemeyer D., 2003. Carbon acquisition of bloom-forming marine phytoplankton. Limnol. Oceanogr., 48, 55-67.

Sangpradub N., Giller P.S. and O'Connor J.P., 1999. Life history patterns of stream-dwelling caddis. Arch. Hydrobiol., 146, 471-493.
Sattler W., 1958. Beiträge zur Kenntnis von Lebensweise und Körperbau der Larve und Puppe von Hydropsyche Pict. (Trichoptera) mit besonderer Berücksichtigung des Netzbaues. Z. Morph. Ökol. Tiere, 47, 115-192.

Schuhmacher H., 1970. Untersuchungen zur Taxonomie, Biologie und Ökologie einiger Köcherfliegenarten der Gattung Hydropsyche Pict. (Insecta, Trichoptera). Int. Rev. Ges. Hydrobiol., 55, 511-557.

Semper K., 1880. Die natürlichen Existenzbedingungen der Thiere, Volumes 1 \& 2, Brockhaus, Leipzig, 299 \& 296 p.

Smart K., 1976. A progress report on the building motivation in the caddis larva, Lepidostoma hirtum. Proc. 1st Int. Symp. Trichopt., 1974, 185-186.

Solem J.O. and Gullefors B., 1996. Trichoptera, caddisflies. In: Nilsson A. (ed.), Aquatic insects of North Europe, Vol. 1, Apollo, Stenstrup, 223-255.

Statzner B. and Bretschko G., 1998. Net-building of a caddis fly (Hydropsyche siltalai) in a French stream: relations with larval density and physical conditions. Arch. Hydrobiol., 144, 87-102.

Statzner B. and Mondy N., 2009. Variation of colour patterns in larval Hydropsyche (Trichoptera): implications for species identifications and the phylogeny of the genus. Limnologica, 39, 177-183.

Statzner B., Kohmann F. and Hildrew A.G., 1991. Calibration of FST-hemispheres against bottom shear stress in a laboratory flume. Freshw. Biol., 26, 227-231.

Statzner B., Arens M.-F., Champagne J.-Y., Morel R. and Herouin E., 1999. Silk-producing stream insects and gravel erosion: significant biological effects on critical shear stress. Water Resour. Res., 35, 3495-3506.

Statzner B., Mérigoux S. and Leichtfried M., 2005. Mineral grains in caddisfly pupal cases and streambed sediments: resource use and its limitation through conflicting resource requirements. Limnol. Oceanogr., 50, 713-721.

Statzner B., Dolédec O. and Sagnes P., 2009. Recent low-cost technologies to analyse physical properties of cases and tubes built by aquatic animals. Int. Rev. Hydrobiol., 94, 625-644.

Statzner B., Douady C.J., Konecny L. and Dolédec S., 2010. Unravelling phylogenetic relationships among regionally co-existing species: Hydropsyche species (Trichoptera: Hydropsychidae) in the Loire River. Zootaxa, 2556, 51-68.

Stevens D.J., Hansell M.H., Freel J.A. and Monaghan P., 1999. Developmental trade-offs in caddis flies: increased investment in larval defence alters adult resource allocation. Proc. R. Soc. Lond. B, 266, 1049-1054.

Stevens D.J., Hansell M.H. and Monaghan P., 2000. Developmental trade-offs and life histories: strategic allocation of resources in caddis flies. Proc. R. Soc. Lond. B, 267, 15111515.

Stuart A.E. and Currie D.C., 2001. Using caddisfly (Trichoptera) case-building behaviour in higher level phylogeny reconstruction. Can. J. Zool., 79, 1842-1854.

Takao A., Kawaguchi Y., Minagawa T., Kayaba Y. and Morimoto Y., 2008. The relationships between benthic macroinvertebrates and biotic and abiotic environmental characteristics downstream of the Yahagi dam, Central Japan, and the state change caused by inflow from a tributary. River Res. Applic., 24, 580-597. 
Tolkamp H.H., 1980. Organism-substrate relationships in lowland streams. Agric. Res. Rep. Wageningen, 907, $1-211$.

Tomer M.D., Dosskey M.G., Burkart M.R., James D.E., Helmers M.J. and Eisenhauer D.E., 2009. Methods to prioritize placement of riparian buffers for improved water quality. Agroforest. Syst., 75, 17-25.

Verneaux J., 1973. Cours d'eau de Franche-Comté (massif du Jura), Doct. Sci. Nat. dissertation, University of Besançon, Besançon, $256 \mathrm{p}$.

Waringer J. and Graf W., 1997. Atlas der österreichischen Köcherfliegenlarven unter Einschluß der angrenzenden Gebiete, Facultas, Wien, 286 p.
Wiggins G.B., 2001. Construction behaviour for new pupal cases by case-making caddis larvae: further comment (Trichoptera: Integripalpia). Braueria, 28, 7-9.

Wiggins G.B., 2004. Caddisflies: the underwater architects, University of Toronto Press, Toronto, 292 p.

Williams D.D. and Feltmate B.W., 1992. Aquatic insects, CAB International, Wallingford, $358 \mathrm{p}$.

Williams D.D., Tavares A.F. and Bryant E., 1987. Respiratory device or camouflage? - A case for the caddisfly. Oikos, 50, 42-52.

Zwick P., 1998. Micrasema longulum (Trichoptera: Brachycentridae) builds a special pupation chamber. Ann. Limnol. - Int. J. Lim., 34, 437-444. 